Wacana, Vol. 7 No. 1 (April 2005): 31-49

\title{
Hubungan intertekstualitas di antara novel-novel Mochtar Lubis
}

\author{
KIM JANG GYEM
}

\begin{abstract}
Mochtar Lubis merupakan tokoh yang selalu gigih memperjuangkan kebenaran, keadilan, kebebasan berpendapat, dan nasib rakyat. Hal itu terlihat dari berbagai aktivitasnya sebagai sastrawan dan wartawan. Dalam setiap karya sastranya, Mochtar Lubis seolah-olah menyatakan dengan jelas pemikirannya. Dengan mengamati hubungan antarteks (intertekstualitas) di dalam karya-karya Mochtar Lubis, dapat dijalin benang merah mengenai persoalan yang selalu didengungkan oleh sastrawan itu dari satu karya ke karya yang lain, seperti ketakutan manusia dan dekadensi moral manusia.

KATA KUNCI

Intertekstualitas, pemaknaan teks, hipogram, hubungan dialektik, transformasi antarteks.
\end{abstract}

Dalam novel-novelnya, Mochtar Lubis seolah-olah menyatakan dengan jelas pendirian, sikap, dan pandangan hidupnya. Jalan Tak Ada Ujung (1952, selanjutnya JTAU), Senja di Jakarta (1981, selanjutnya SDJ), Tanah Gersang (1982, selanjutnya TG), Maut dan Cinta (1989, selanjutnya MDC), Tidak Ada Esok (1989, selanjutnya TAE), dan Harimau! Harimau! (1992, selanjutnya HH) adalah novel-novel yang mengungkapkan kehidupan manusia-manusia yang menjadi korban zamannya. Keenam novel tersebut dengan jelas dan gamblang menampilkan wajah-wajah manusia yang terkungkung materialisme. Martabat manusia diukur dengan benda, korupsi yang merajalela, dan nilainilai moral yang tidak dihayati dan dijalankan dengan semestinya. Akibatnya, timbul pelbagai konflik dalam hati nurani para tokoh ceritanya.

Novel-novel Mochtar Lubis selaras dengan pandangannya itu. Mochtar Lubis selalu menampilkan tokoh-tokoh yang mengalami konflik hati nurani,

KIM JANG GYEM, lahir di Cheun Ahn, Provinsi Chung Nam (3 Februari 1962); menyelesaikan pendidikan sarjana dan magister di Jurusan Malay-Indonesia HUFS (Hankuk University of Foreign Studies) tahun 1986; kemudian menyelesaikan pendidikan magister dan doktor di Fakultas Sastra Universitas Gadjah Mada tahun 1996; tahun 1997 sampai sekarang menetap sebagai Senior Research Fellow dan Adjunct Professor di Center for International Area Studies HUFS; artikel-artikelnya pernah dimuat di The Southest Asian Review dan Journal of International Area Studies dan; menerjemahkan Mahabharata.

(C) 2011 Faculty of Humanities, University of Indonesia 
yakni antara yang hendak berbuat baik dan yang berbuat jahat, benar dan salah. Keenam novel Mochtar Lubis relatif mengemukakan persoalan yang sama. Novel-novelnya yang terbit kemudian seolah memberikan penegasan atas persoalan yang telah dikemukakan dalam novel sebelumnya. Dengan kata lain, novel-novelnya yang terdahulu merupakan hipogram bagi novelnovelnya yang kemudian. Karena itu, sangat menarik mengkaji hubungan intertekstualitas di antara keenam novel tersebut, baik secara sinkronis maupun diakronis. Telaah semacam itu tentu akan memberikan satu gambaran persoalan apa saja yang mendapat atau yang tidak mendapat tekanan. Dengan demikian, dapat dilihat perkembangan pemikiran atau perhatian pengarang terhadap satu persoalan dari waktu ke waktu seiring dengan penerbitan teks sastranya

\section{HUBUNGAN INTERTEKSTUALITAS}

Hubungan intertekstualitas atau hubungan antarteks merupakan satu fenomena umum dalam teks-teks sastra atau teks-teks lain. Tidak ada teks sastra yang muncul dari kekosongan teks-teks lain. Setiap teks sastra merupakan satu mozaik kutipan-penyerapan atau pentransformasian teksteks yang sudah ada sebelumnya (Kristeva dalam Culler 1981:107). Meskipun demikian, hubungan intertekstualitas bukanlah soal pengaruh teks yang telah ada sebelumnya itu. Riffaterre, yang dikutip oleh Zaimar (1981: 26), menyatakan bahwa hubungan intertekstualitas adalah

\footnotetext{
"suatu fenomena yang mengarahkan pembacaan teks, yang mungkin menentukan interpretasi, dan yang kebalikan dari pembacaan perbaris." Itu adalah cara untuk memandang teks yang menentukan makna wacana, sedangkan pembacaan per baris hanya menentukan makna unsurnya. Berkat cara memandang teks semacam itu, pembaca sadar bahwa dalam suatu karya sastra, kata-kata tidaklah mengacu pada benda-benda atau konsep atau secara umum tidak mengacu pada dunia yang bukan kata-kata (noverbal) [sic!]. Di sini kata-kata mengacu pada suatu jalinan pemunculan yang secara keseluruhan sudah menyatu dengan dunia bahasa. Jalinan itu dapat berupa teks-teks yang telah dikenal ataupun bagian-bagian dari teks yang muncul setelah terlepas dari konteksnya dan yang dapat dikenali dalam konteksnya yang baru, sehingga orang tahu bahwa teks tersebut telah ada sebelum ia muncul dalam konteks yang baru ini.
}

Dari kerangka pemikiran di atas jelaslah bahwa bagi Riffaterre pemaknaan suatu teks tidak hanya ditentukan oleh unsur-unsur yang ada di dalam teks itu sendiri (unsur-dalam), tetapi juga oleh unsur-unsur yang berada di luarnya (unsur-luar). Namun, di dalam penelitian ini hanya diperlihatkan pemaknaan teks dari sastra sendiri (dalam). Hubungan unsur-dalam satuan makna secara keseluruhan (matriks) ditentukan atau setidaknya ditopang oleh hubungan unsur-unsur itu dengan unsur-luar yang menjadi hipogramnya. Hubungan intertekstualitas antara teks yang ada dengan teks sebelumnya itu, dalam studi ini, disebut sebagai hubungan hipogramatik. Hubungan hipogramatik adalah hubungan antara suatu teks dan teks yang ada sebelumnya dalam rangka penentuan satuan makna teks yang bersangkutan. 
Meskipun demikian, menurut Riffaterre (1978: 23), sebuah unsur-dalam yang menjadi tanda puitis tidak hanya mengacu kepada teks lain yang menjadi hipogramnya, tetapi juga menjadi bagian integral matriks teksnya sendiri. Dengan demikian, terbuka kemungkinan kesenjangan dan ketegangan antara tanda yang bersangkutan dengan hipogramnya. Sebuah teks tidak hanya menerima dengan setia signifikansi yang terbangun dalam teks hipogram yang menjadi acuannya, tetapi dapat pula merupakan transformasi, apakah dalam bentuk pembalikan maupun dalam bentuk penentangan atau negasi (Culler 1981: 83, 88-89).

Persoalan hubungan transformasi antarteks dapat didefinisikan sebagai suatu hubungan persamaan bentuk antara suatu teks yang menjadi hipogram dan teks yang mengacunya. Hanya saja, persamaan itu terbatas pada kerangka dasarnya, sedangkan pada bentuk permukaannya terdapat perbedaan antara keduanya. Hal ini dapat dilihat misalnya dalam hubungan antara berbagai bentuk transformasi dari konsep beauty and the beast yang dianalisis secara panjang lebar oleh Riffaterre, terutama dalam kaitannya dengan puisi Baudelaire yang berjudul Fleurs du Mal (Riffaterre 1978: 23-25).

Mengenai kemungkinan adanya hubungan pembalikan dan penentangan dalam hubungan intertekstualitas di atas, teori Harold Bloom dapat digunakan sebagai penegasan. Bloom (dalam Culler 1981:107-109) menganggap sebuah teks sastra selalu terikat dan cenderung meniru apa yang sudah disediakan oleh tradisi. Oleh sebab itu, menurut Bloom, seorang penyair sublim selalu berjuang untuk melakukan perlawanan terhadapnya. Tradisi yang dilawan oleh penyair itu bukan satu sistem wacana yang anonim, melainkan teks-teks sastra yang konkret hasil karya pendahulunya yang dominan. Culler (1981: 109) menyebut teori Bloom ini sebagai "kritik antitesis". Dalam studi ini teori itu disebut dengan istilah dialektis sesuai dengan gagasan mengenai perjuangan (struggle) yang terkandung di dalamnya. Dengan menyebutnya sebagai teori dialektis, teori Bloom tidak hanya dikembangkan dengan persoalan hubungan antitesis antarteks, tetapi juga dengan kemungkinan hubungan sintesisnya. Di dalam analisis ini, dengan pengarahan pada keenam teks kajian, kemungkinan terbesar hubungan dialektis itu menunjukkan adanya sintesis.

HUBUNGAN INTERTEKSTUALITAS ANTARENAM NOVEL: HUBUNGAN TRANSFORMATIF

TAE merupakan novel yang mengalami kesenjangan waktu yang relatif lama dalam hal jarak antara penerbitan pertamanya dan penerbitannya yang kedua, yaitu selama sekitar 32 tahun, sejak tahun 1950 hingga 1982. Meskipun demikian, hal itu tidak berarti bahwa novel tersebut hilang dalam waktu tersebut. Sebagai novel pertama, novel tersebut ternyata mengandung banyak potensi yang kemudian menjadi bahan bagi novel-novel berikutnya. TAE memiliki kandungan persoalan yang luas dan beraneka di seputar (i) ketakutan; (ii) keberanian; (iii) keputusasaan; (iv) harapan; (v) perjuangan dan kemerdekaan; (vi) kebodohan dan kebobrokan moral; (vii) kedudukan bangsa Indonesia di tengah-tengah bangsa lain; (viii) kebudayaan dan peradaban 
umat manusia; (ix) kualitas para pemimpin politik ; dan (x) nasib rakyat kecil di pedesaan.

Dari berbagai persoalan di atas, yang terbaca menduduki posisi dominan adalah persoalan ketakutan dan kecemasan akan "kegelapan" masa depan yang disertai dengan keberanian, perjuangan, dan harapan akan masih adanya "hari esok". Persoalan ini diwujudkan dalam berbagai bentuk kejadian dan peristiwa. Salah satunya adalah perjuangan diplomatik yang dilakukan oleh para pemimpin politik tidak banyak membawa hasil. Dalam kenyataannya pihak musuh terus saja mencengkeramkan kuku-kukunya di bumi Indonesia. Yang paling menderita atas keadaan itu adalah rakyat kecil. Rakyat hidup dalam ketakutan dan frustrasi. Mereka takut karena hidup tidak bebas merdeka dan frustrasi karena telah lama dijajah sehingga mental bangsa menjadi rusak (TAE: 43). Pada akhirnya, rakyat berpikir secara stereotip: menganggap semua orang asing adalah musuh (TAE: 42). Dalam novel tersebut ketakutan menyerang seluruh lapisan masyarakat, tidak saja masyarakat perkotaan, tetapi juga perdesaan, demikian pula anak muda, yang tidak saja laki-laki, tetapi juga wanita.

Novel berikutnya, yaitu JTAU, juga masih melanjutkan persoalan sentral tersebut, yaitu persoalan ketakutan. Akan tetapi, terdapat perbedaan di antara keduanya. Bila ketakutan dalam novel pertama dikisahkan menyerang seluruh lapisan masyarakat, dalam hal struktur, ketakutan dalam novel kedua dibatasi oleh ruang lingkup yang lebih sempit. Dalam novel kedua, ketakutan itu cenderung ditekankan ke wilayah yang lebih terbatas dan sempit, yaitu ketakutan psikologis tokoh. Karena penyempitan itu, persoalan ketakutan yang ada di dalamnya menjadi terungkap secara lebih intensif, masuk ke bagian terdalam dari batin tokoh sehingga terasa lebih menyentuh batin pembaca. Hal seperti itu tidak terbaca pada novel pertama. Novel pertama menyinggung ketakutan secara sporadis dan hanya menyentuh tahap permukaan. Pergolakan batin tokoh dalam mengatasi ketakutan tidak dikisahkan secara rinci.

Intensifikasi persoalan ketakutan itu berkaitan dengan tokoh sentral cerita dan fungsi tekstualnya. Tokoh sentral dalam novel pertama berbeda dengan tokoh sentral dalam novel kedua. Johan (dalam TAE) merupakan tokoh yang mempunyai ketakutan tersembunyi di dalam hatinya. Akan tetapi, tokoh ini digambarkan sebagai tokoh yang mempunyai daya tahan dan daya lawan yang cukup kuat. Johan selalu mampu menekan ketakutan yang ada di dalam hatinya sehingga ketakutan-ketakutannya hanya muncul sekali-sekali ke permukaan, ke wilayah kesadarannya. Salah satu bentuk ketakutannya terbaca sebagai berikut.

Akan matikah dia malam ini? Tidak, dia takkan mati. Dia akan selamat ke luar dari perjuangan ini. Yang lain mati. Ya. Tetapi tidak dia. Siapa tahu dia barangkali akan mati juga? Tidak. Barangkali? Dia menjilat bibirnya kembali dengan lidahnya. Rasa takut yang selamanya memeras hatinya setiap pertempuran hendak terjadi, datang menyerangnya. (TAE: 9) 
Mungkin karena intensitas ketakutannya itu tidak terlalu tinggi, tidak seperti Guru Isa dalam JTAU, Johan ditampilkan sebagai seorang pejuang yang aktif, pejuang yang melibatkan dirinya dalam peperangan atas dasar pilihan sadarnya. Hal itu karena adanya dorongan untuk "memulai hidup baru, hidup untuk sesuatu yang lebih besar, untuk bangsanya" (TAE: 90). Oleh sebab itu pula, tokoh ini diberi nama Johan yang berarti 'pemenang', tokoh yang berhasil mengalahkan ketakutannya. Meskipun cerita menyebutkan bahwa pada akhirnya Johan mati terkena pecahan mortir, tokoh tersebut mati dengan tersenyum, dengan "girang". Hal itu terjadi sebab Johan menyadari bahwa masih ada "hari esok" . Hari esok atau masa depan itu disimbolkan dengan bayi yang lahir dan menangis keras tepat di kalimat terakhir cerita, "bayi yang baru lahir itu menangis, berteriak" (TAE: 226) dan hari esok yang akan memberikan harapan bagi "ibu tua, anak-anaknya, gadis perawan kecil, ketiga anak laki-laki, ibu muda, dan bayi yang baru lahir." (TAE: 224).

Persoalan yang muncul di sekitar tokoh Johan itu berbeda dengan tokoh sentral novel kedua, Guru Isa. Guru Isa terbaca sebagai tokoh yang sama sekali tidak memperlihatkan keberaniannya di sepanjang cerita. Ia adalah seorang guru yang hidup dalam serba tidak berdaya, baik sebagai suami pencari nafkah, lelaki pemuas kebutuhan seks, maupun sebagai pejuang. Berbeda dengan Johan yang memang melibatkan diri dalam peperangan secara sadar dan aktif, Guru Isa terlibat dalam peperangan secara sadar dan pasif. Oleh sebab itu, keterlibatan itu sama sekali bukan karena adanya kekuatan keberdayaan di dalam dirinya sendiri, seperti yang dimiliki oleh Johan, melainkan karena ketakutannya, baik dalam bentuk cakapan di dalam hati maupun dengan Fatimah (JTAU: 55) . Ketakutan Guru Isa adalah ketakutan total. Oleh sebab itu, kedudukan sebagai tokoh sentral membuat persoalan ketakutan di dalam JTAU hadir jauh lebih dalam dan luas dibandingkan dengan persoalan serupa yang terdapat di dalam TAE.

Meskipun demikian, di dalam novel JTAU juga terbaca persoalan keberanian. Akan tetapi, keberanian dan ketakutan di dalam TAE merupakan bagian lain dari diri Johan, atau, dengan kata lain, terdapat di dalam diri seorang tokoh saja. Sebaliknya, di dalam JTAU keberanian ditempatkan pada diri tokoh lain, yaitu Hazil. Dengan kata lain, keberanian di sini tidak tercampur dengan ketakutan yang secara total terdapat dalam diri Guru Isa. Dalam rangka fungsi struktur, keberanian yang ditempatkan pada diri Hazil mempertegas sifat penakut Guru Isa. Meskipun demikian, perlu dicatat bahwa keberanian Hazil adalah keberanian semu, keberanian yang dibuat-buat. Keberanian itu muncul untuk munutupi sifat penakutnya. Keberanian semu itu terbongkar ketika Hazil disiksa di dalam penjara seperti yang tampak dalam kutipan berikut.

Hazil menundukkan matanya, mengelakkan pandangan Guru Isa. Aku berkhianat, aku khianati dia, tuduhnya pada dirinya sendiri, sekarang dia di sini, menghadapi siksaan seperti aku, karena aku pengecut, tidak tahan siksaan, dan Hazil ... menangis terisak-isak seperti anak kecil. (JTAU: 111) 
Di samping keberanian semu, terdapat pula keberanian hakiki. Hal itu terlihat pada diri tokoh Guru Isa. Seperti terbaca pada bagian paling akhir novel itu, Guru Isa akhirnya mendapatkan keberanian dirinya. Guru Isa tidak lagi takut pada siksaan yang diterimanya setiap hari di penjara. Akan tetapi, keberanian Guru Isa itu benar-benar hanya muncul di akhir cerita. Potensi keberaniannya tidak pernah ditampakkan sebelumnya. Selain itu, keberanian Guru Isa pun muncul bukan atas dasar usaha perlawanan dan perjuangannya sendiri secara aktif. Keberanian Guru Isa muncul sebagai puncak akumulasi ketakutannya. Ketakutan yang begitu memuncak, mencekam, dan membuat Guru Isa kehilangan harapan untuk bebas dari kekuatan justru menghasilkan kesadaran. Guru Isa memang tidak mengalami perubahan dari takut menjadi pemberani, malainkan dapat berdamai dengan rasa takutnya. Hal itu terlihat dalam kutipan berikut.

Dia telah menguasai dirinya sendiri. Tiada benar dia tidak merasa takut lagi. Tetapi dia telah damai dengan takutnya. Telah belajar bagaimana harus hidup dengan takutnya. ... Kelaki-lakiannya telah kembali! Dan dia ingin melompat dan berteriak menyatakan kebahagiaannya kepada seluruh dunia. Di luar langit bertambah-tambah biru dan bertambah-tambah putih. Guru Isa berdiri di depan jendela, memegangi jeriji besi dengan kedua tangannya. (JTAU: 115)

Di dalam novel berikutnya, yakni SDJ, persoalan ketakutan yang sentral dalam TAE dan JTAU tidak lagi menduduki posisi tersebut dalam rangka struktur. Dalam rangka fungsi tekstual, novel ketiga ini justru memperluas bagian yang di dalam novel pertama menempati posisi marginal, pinggiran, dari novel yang pertama, yaitu persoalan kebobrokan moral. Apabila di dalam TAE persoalan kebobrokan moral itu hanya terlihat dalam dialog dan perdebatan antartokoh dalam adegan tertentu, antara lain berupa perampokan, pembunuhan, pencurian, dan perzinahan, di dalam SDJ persoalan tersebut menjadi sentral dan menyebar di berbagai lapisan teks dan latar cerita. Dengan kata lain, dalam rangka fungsi struktur, persoalan itu dieksploitasi secara intensif.

Struktur SDJ bersifat kompleks karena mengandung sejumlah digresi. Digresi itu merupakan cerita kehidupan sejumlah manusia dalam berbagai lingkungan masyarakat, baik lingkungan masyarakat atas, menengah, maupun bawah. Novel tersebut menggambarkan hampir secara lepas-lepas kehidupan berbagai lingkungan di atas melalui tokoh-tokoh tertentunya. Adapun kehidupan yang ada di berbagai lingkungan tersebut hampir seluruhnya digambarkan sebagai kehidupan yang dekaden, antara lain (1) dekadensi kehidupan politik, (2) dekadensi kehidupan ekonomi, (3) dekadensi kehidupan media cetak, (4) dekadensi kehidupan rumah tangga, (5) dekadensi hubungan seksual anak dan ibu tiri, dan (6) dekadensi hubungan laki-wanita pada masyarakat kelas bawah.

Dalam rangka fungsi, intensif dan ekstensifnya persoalan dekadensi dalam novel SDJ juga merasuk ke dalam diri tokoh utamanya, yakni Suryono. Tokoh ini terbaca sebagai penganut paham eksistensialisme yang tidak memedulikan 
kepentingan orang lain selain dirinya sendiri. Rasa keakuannya demikian tinggi. Akan tetapi, Suryono sendiri tidak dapat sepenuhnya dianggap sebagai tokoh utama karena banyak bagian dan peristiwa yang terlepas dari dirinya. Novel ini hampir tidak mempunyai tokoh utama seorang hero yang bernilai baik. Dalam rangka fungsi tekstual, unsur tokoh berwatak baik seperti Idris tidak dieksploitasi, sementara Hasnah yang juga baik hanya menjadi pelengkap kehidupan suaminya, Sugeng. Dalam novel ini, seluruh individu, seluruh lapisan masyarakat, dan seluruh lingkungan cenderung dilukiskan sebagai dekaden. Itulah sebabnya, berbeda dari TAE dan JTAU yang masih menyiratkan adanya harapan untuk keluar dari persoalan (ketakutan), novel ini menutup sama sekali harapan itu. Novel ini mengakhiri ceritanya dengan peristiwa kejahatan yang juga dekaden sebagaimana terlihat dalam satuan naratif yang termasuk ke dalam "Laporan Kota", yang terdapat di setiap akhir bab. Berikut adalah contohnya.

Malam telah memeluk ibu kota dalam pelukannya yang erat. Jalan-jalan telah jadi sepi. Kemudian hujan bercampur topan yang dihembuskan angin dari laut datang melanda Jakarta. Akan tetapi dalam malam itu ada sosok-sosok tubuh hitam mengendap-endap mencari jalan, memasuki rumah-rumah orang yang tidur pulas, pencuri-pencuri malam yang menjalankan pekerjaan mereka. (SDJ: 340 - 341)

Dalam rangka fungsi tekstual teksnya, persoalan dekadensi membuat SDJ potensial menjadi bahan dasar untuk dikembangkan, misalnya persoalan kejahatan yang dilakukan oleh anak muda dan persoalan ketidakharmonisan kehidupan rumah tangga. Cerita tentang anak yang kehilangan kasih sayang terlihat pada diri Suryono, sedangkan cerita tentang kriminalitas anak muda terdapat pada diri Jok dan Tony. Kedua cerita itu dapat dikatakan merupakan dua buah cerita yang terpisah, dalam arti, persinggungannya cuma sedikit. Persamaan di antara kedua cerita tersebut adalah dalam kesejajaran tematis.

Kedua cerita yang terpisah dalam novel SDJ kemudian dimanfaatkan menjadi sebuah cerita yang integral dalam novel TG dalam rangka fungsi tekstualnya. Seperti halnya Jok dan Tony dalam SDJ, Joni dalam TG terlihat sebagai anak muda yang terlibat dalam tindakan kriminal dengan berbagai macam bentuk kekerasan. Akan tetapi, latar belakang keterlibatan Joni dan kawan-kawannya itu tidak diambil dari cerita tentang Jok dan Tony, melainkan lebih dekat dengan cerita latar belakang kehidupan Suryono dalam SDJ. Hanya saja, pada diri Suryono persoalannya lebih rumit. Di samping tidak pernah mendapatkan kasih sayang dari orang tuanya, tindakan dekaden yang dilakukan Suryono juga didorong oleh falsafah eksistensialisme yang diyakininya. Hal serupa terlihat juga pada Joni. Tindakan-tindakan kriminalitas yang dilakukannya juga secara tersirat karena penempatan eksistensi diri yang berlebih sebagai akibat kegersangan jiwa - kegersangan jiwa karena ketiadaan siraman nilai-nilai humanistis pada dirinya.

Di dalam novel SDJ, kedua cerita tersebut merupakan sebagian saja dari keseluruhan persoalan cerita dekadensi moral masyarakat yang amat meluas dan meliputi berbagai lapisan. Dalam rangka fungsi tekstual, di dalam novel 
keempat (TG), kedua cerita yang terpisah itu tidak hanya dipersatukan menjadi cerita yang utuh dengan menempatkannya di dalam diri seorang tokoh, melainkan juga diintensifkan dengan penambahan beberapa tokoh muda lainnya. Yang dimaksud di sini adalah teman-teman kriminal Joni, yakni Yusuf dan Sukandar, serta Lisa, yang juga mempunyai latar belakang kehidupan keluarga yang kurang harmonis.

Selanjutnya, bila di dalam kedua novel yang terakhir itu, SDJ dan TG, dalam rangka fungsi struktur persoalam ketakutan cenderung ditempatkan pada bagian pinggiran setelah menduduki posisi sentral pada novel pertama dan kedua (TAE dan JTAU), di dalam novel kelima, HH, persoalan itu kembali difungsikan dan menduduki posisi sentral. Akan tetapi, novel ini tidak pula sama sekali terlepas dari novel yang ketiga dan keempat. Dalam rangka fungsi, persoalan ketakutan dan cara mengatasinya itu merata pada masing-masing unsur tokohnya, kecuali Pak Haji. Pak Balam mengatasi rasa takutnya dengan membongkar dosa lama yang dilakukannya bersama Wak Katok semasa perjuangan. Karena usahanya tidak segera membawa hasil, Pak Balam terus memaksa Wak Katok mengakui dosa-dosanya agar harimau siluman, yang diyakini Pak Balam, tidak menyerang mereka. Wak Katok yang juga ketakutan mengatasi ketakutannya dengan menekan orang lain. Dengan cara demikian, Wak Katok berharap dapat bertindak sebagai tokoh yang pemberani dan pelindung anggota pencari damar. Akan tetapi, yang terjadi justru sebaliknya. Konflik yang terjadi dalam batinnya menyebabkan Wak Katok lengah mengisi mesiu sehingga gagal menembak harimau. Dari kegagalan itu, citra Wak Katok sebagai manusia penakut menjadi transparan di mata orang lain, terlebih-lebih ketika diketahui oleh Buyung, Sanip, dan Pak Haji bahwa Wak Katok terkencing-kencing di dalam celana karena takut diterkam harimau. Dengan demikian, citra Wak Katok yang semula positif menjadi runtuh.

Demikian pula halnya dengan tokoh Sanip dan Sutan; keduanya juga mengalami ketakutan yang luar biasa. Ketakutan itu terutama sekali adalah ketakutan akan diterkam harimau karena keduanya yakin bahwa harimau yang akan memangsa mereka adalah harimau siluman. Oleh sebab itu, dalam puncak ketakutan keduanya tanpa perasaan malu mengakui perbuatan dosa mereka di depan orang lain.

Lain halnya dengan Buyung, tokoh yang memiliki kepribadian yang kuat. Buyung berani bersikap dan menentang Wak Katok. Dalam rangka fungsi, tokoh ini digambarkan sebagai seorang idealis. Dikisahkan bahwa Buyung memegang prinsip lebih baik mati daripada harus menceritakan dosa yang pernah dilakukannya. Kenekatan Buyung itu membuat Wak Katok menjadi ragu-ragu untuk memaksa Buyung. Sikap Buyung yang berani menentukan sikap itu memiliki kesamaan dengan Johan dalam TAE dan kelak dieksploitasi lebih jauh pada diri Sadeli dalam rangka fungsi tekstual MDC.

Persoalan ketakutan yang hampir merata menyerang seluruh unsur tokoh dalam novel HH ini dan cara setiap tokoh menyelesaikan ketakutannya dapat dipandang sebagai suatu bentuk kombinasi baru atas persoalan-persoalan 
yang terdapat di dalam novel pertama (TAE) dan kedua (JTAU) dengan novel ketiga (SDJ) dan keempat (TG).

Selanjutnya, dalam rangka fungsi tekstual, novel keenam bergerak kembali kepada novel pertama, mengintensifkan dan mengekstensifkan persoalan yang sedikit disentuh dalam novel pertama itu. Dalam TAE persoalan diplomasi politik sebagai cara terbaik bagi perjuangan bangsa hanya tampil di sebagian kecil cerita, yakni di dalam dialog antara Johan dan Kapten Sudiarto (TAE: 177-180). Dalam dialog itu, diplomasi dipandang sebagai metode perjuangan yang ideal dan sulit dilakukan karena berbagai faktor. Sebaliknya, di dalam MDC persoalan itu menjadi persoalan sentral. Novel MDC dapat dianggap merealisasikan apa yang di dalam novel sebelumnya hanya merupakan persoalan ideal. MDC bercerita mengenai keampuhan diplomasi politik yang dilakukan oleh tokoh utamanya, Sadeli, yang ditugaskan oleh Kolonel Suroso. Dalam perjuangan itu, Sadeli berdiplomasi dengan Inspektur Hawkins (MDC: $32-35)$, perwira Inggris yang berkuasa di Singapura, dengan David Wayne, Pierre de Kooning, Derek Scott, (MDC: 128 -137), dan juga dengan Dr. Banerji, tokoh perjuangan India (MDC: 91-94).

Kepiawaian Sadeli berdiplomasi membuahkan hasil yang memuaskan. Inspektur Hawkins yang semula mencurigai kehadiran Sadeli di Singapura, pada akhirnya bukan saja menaruh hormat kepada Sadeli, tetapi juga bersimpati kepada perjuangan rakyat Indonesia. Perwujudan rasa simpatinya terlihat dari (i) usahanya mendapatkan izin bagi Sadeli untuk membawa senjata, (ii) memberikan berbagai informasi yang dibutuhkan Sadeli mengenai tokoh-tokoh pedagang di Singapura, (iii) memberikan saran kepada Sadeli agar melakukan tindakan tertentu dan tidak melakukan yang lainnya, dan (iv) mengakui Sadeli sebagai seorang sahabat. Dengan perlakuan yang demikian, berbagai urusan yang dijalankan Sadeli di Singapura berjalan lancar dan untuk seterusnya ia melancarkan perjuangan yang dilakukan kawan-kawannya di dalam negeri.

Keampuhan diplomasi yang dijalankan Sadeli juga terlihat dari kesediaan David Wayne dan kawan-kawannya membantu perjuangan bangsa Indonesia. Dalam rangka fungsi, Sadeli digambarkan mengerahkan seluruh kemampuan intelektualnya ketika berdebat dengan David Wayne. Sadeli menjelaskan arti dan makna perjuangan bangsa Indonesia. Sadeli juga menjelaskan bahwa perjuangan yang dilakukan bangsa Indonesia bukan hanya untuk meraih kemerdekaan, melepaskan diri dari penjajahan, tetapi lebih mulia, yakni melepaskan manusia dari belenggu yang membuat manusia tidak hidup dengan layak.

Dalam novel ini, diplomasi menjadi satu bentuk perjuangan yang tidak kalah pentingnya dengan perjuangan fisik sebagaimana digambarkan dalam TAE. Tiap-tiap bentuk perjuangan itu mempunyai nilai lebih dan saling melengkapi. Oleh sebab itu pula, dalam MDC perjuangan diplomasi Sadeli diilustrasikan pula dengan perjuangan fisik sebagaimana terlihat dalam pertempuran Sadeli dan kawan-kawannya menghadapi serangan korvet Belanda. Dalam rangka fungsi tekstual, pemanfaatan ilustrasi itu bermakna 
bahwa perjuangan fisik dan diplomatik sama penting kedudukannya dalam mewujudkan cita-cita perjuangan bangsa.

\section{HUBUNGAN INTERTEKSTUALITAS ANTARENAM NOVEL: HUBUNGAN DIALEKTIK}

Unsur struktur novel TAE tidak hanya menyediakan serangkaian permasalahan yang dapat dikembangkan, diperluas atau dipersempit, diintensifikasi atau diekstensifikasi bagi novel-novel sesudahnya, tetapi juga menyediakan aneka ragam masalah yang luas, yang dapat dilihat dari berbagai sudut pandang. Di dalam novel yang pertama itu, ketakutan lebih dipahami sebagai akibat sikap egosentris seseorang, dalam hal ini Johan, sehingga pemecahannya dapat dilakukan dengan mempertautkan diri orang itu pada kepentingan yang lebih besar, yaitu kepentingan bangsa ataupun kepentingan orang lain. Johan berusaha menghilangkan ketakutannya dengan mencoba memberi makna bagi kehidupan pribadinya. Johan melibatkan diri dalam perjuangan fisik yang semula tidak disukainya. Melalui cara demikian, makna dirinya sebagai seorang individu, warga masyarakat, warga negara, warga dunia, dan sebagai makhluk ciptaan Tuhan menjadi lebih utuh dan sempurna.

Dalam rangka fungsi tekstual, persoalan ketakutan dalam novel kedua, JTAU, dipahami sebagai akibat tekanan dari luar yang tidak dapat dilawan sehingga untuk mengatasinya, Guru Isa hanya dapat menempuh satu jalan, yaitu pasrah. Dengan sikap itu, ketakutan-ketakutan lain yang mungkin lebih besar relatif dapat ditekan meskipun tetap saja merusak jiwa bersangkutan. Sebagaimana terbaca dalam teksnya, Guru Isa pasrah menerima penunjukan dirinya sebagai (i) seorang kurir dalam gerakan bahwa tanah, (ii) bendahara gerakan bahwa tanah, dan (iii) penggranat Bioskop Rex. Guru Isa juga pasrah menerima (iv) kehadiran Hazil, yang baginya merupakan mimpi buruk dalam kehidupannya, dan (v) perlakuan dingin istrinya. Guru Isa tidak dapat mengelakkan semua yang datang dari luar karena jiwanya tidak memiliki keberanian untuk menolaknya. Keinginan untuk menolak ada dan terbaca dalam pikiran-pikiran Guru Isa. Akan tetapi, keinginan-keinginan itu hanya sekadar keinginan yang tidak disertai oleh tindakan, bahkan tidak berani dikomunikasikan kepada orang lain. Di sepanjang teks terbaca hanya satu kali Guru Isa berani mengomunikasikan perihal ketakutan-ketakutannya itu, yakni kepada Fatimah.

Di dalam $\mathrm{HH}$, novel kelima, ketakutan itu dianggap sebagai akibat dari dorongan-dorongan yang ada di dalam diri individu masing-masing, terutama dorongan-dorongan yang mengakibatkan Wak Katok, Pak Balam, Pak Haji, Sutan, Sanip, Talib, dan Buyung melakukan kejahatan dan kesalahan, baik terhadap orang lain, masyarakat, maupun Tuhan. Oleh sebab itu, ketakutan itu hanya dapat diatasi apabila individu yang bersangkutan berhasil menguasai dirinya sendiri. Dalam rangka fungsi tekstual, terbaca pada teksnya, tokoh yang berhasil menguasai diri adalah Buyung dan Pak Haji, sementara tokohtokoh lainnya tidak. Keberhasilan Pak Haji disebabkan oleh pembawaan sikapnya yang tenang. Di samping itu, Pak Haji dilukiskan sebagai tokoh yang 
telah melanglang buana ke banyak negara serta telah merasakan berbagai rintangan. Rintangan yang dihadapinya di hutan bersama anggota kelompok pencari damar, yang tidak lain bersumber pada diri Wak Katok, tidak mengejutkannya. Pak Haji sudah mengetahui sifat dan watak Wak Katok. Oleh sebab itu, sebagai orang tua yang telah banyak mengecap asam garam kehidupan, Pak Haji tidak mengalami konflik batin yang kuat sebagaimana tokoh-tokoh lainnya. Dalam pada itu, Buyung berhasil mengatasi rasa takutnya karena kepribadiannya kuat. Buyung berani bersikap dan melawan ancaman Wak Katok. Buyung juga bersikap rasional dalam menghadapi berbagai kejadian. Dengan sikap itu, Buyung tampil sebagai tokoh orang muda yang tegar dan tidak mudah panik. Benar bahwa ketakutan juga menyerangnya. Akan tetapi, karena dosa-dosa yang pernah dibuatnya relatif masih sedikit, ketakutan akibat konflik batin tidak begitu terasa kuat.

Dalam rangka fungsi, novel pertama, TAE, memanfaatkan adanya konflik antara kebangsaan dan kemanusiaan. Dalam konflik itu, kemanusiaan akhirnya dikalahkan oleh sikap kebangsaan sebab paham yang pertama dapat membuat orang menjadi individualistis, tidak memedulikan nasib rakyat dan bangsanya. Perihal ini terlihat dalam pandangan Johan sebelum bertemu dengan Hassan maupun di awal perdebatannya dengan Hassan. Johan tidak senang menyaksikan perlakuan sebagian masyarakatnya yang memandang rendah bangsa lain (TAE: 42-43). Hal itu karena falsafah yang diyakini Johan adalah falsafah humanisme universal, yakni falsafah yang tidak membedabedakan manusia karena warna kulit atau kewarganegaraannya. Begitu juga ketika Johan berdiskusi dengan Hassan, falsafah serupa diajukannya sebagai satu alternatif pemecahan masalah(TAE: 85-87). Akan tetapi, paham kemanusiaan yang dipegang Johan itu terkalahkan oleh falsafah kebangsaan atau nasionalisme yang diwakili Hassan. Hassan menunjukkan dan membuktikan kepada Johan bahwa pada masa peperangan sikap mempertahankan bumi adalah sikap yang benar seperti yang tampak dalam kutipan berikut.

\footnotetext{
“Tanah ini takkan lari. Selamanya ada di sini. Menunggu dengan sabar. Lihatlah tanah ini, Jon," dan dilemparkannya sekeping tanah basah kepada Johan. "Segumpul tanah yang subur. Tanah kita. Tanah nenek moyang kita. Tanah bumi kita. Tanah tempat nenek moyang kita berburu. Tempat mereka mengambil makanan untuk hidup. Supaya kita hidup. Tempat mereka mati dan dikubur. Setiap aku bersentuhan dengan tanah ini, aku merasakan tenaga gaib yang dikandungnya. Kesucian dan kebesaran tanah air. Lihatlah orang-orang Rusia, Perancis, Inggeris, Belanda, Yunani, Yugoslavia, orang-orang Cina dan bangsa-bangsa lain itu berperang sekarang. Mengorbankan jiwanya. Apakah yang mereka pertahankan. Tidakkah dalam hakikatnya agar janganlah sepatu atau kaki bangsa asing berinjak di keping-keping bumi mereka? Kepingan tanah seperti yang kita genggam ini juga. Mereka punya. Kita punya. Mereka mati agar buminya merdeka? Tidakkan demikian?" (TAE: 81)
}

Dalam rangka struktur, cara pandang dalam melihat persoalan tersebut justru berbalik dalam JTAU. Kebangsaan tidak dapat menaklukkan kemanusiaan, melainkan justru sebaliknya. Hazil sebagai simbol kebangsaan, 
orang yang menyerahkan dirinya pada peperangan dalam perjuangan kebangsaan, akhirnya menjadi penakut. Sebaliknya, Guru Isa yang lebih banyak terlibat pada konflik-konflik batin sendiri daripada konflik-konflik eksternal kebangsaan justru menjadi berani.

Sikap kebangsaan Hazil terlihat dari jalan pikiran serta tindakan-tindakan yang diambilnya. Begitu mendengar tembakan di Gang Jaksa, Hazil dengan sigap keluar dari rumah sambil membawa pistol, "untuk perjoangan kemerdekaan" (JTAU: 20) tanpa memedulikan keberatan ayahnya, "dalam perjuangan kemerdekaan ini tidak ada tempat pikiran kacau dan ragu-ragu" (JTAU: 39). Menghadapi api nasionalisme Hazil yang menggebu-gebu, Guru Isa ketakutan. Dalam diri Guru Isa tidak pernah terlintas untuk melakukan kekerasan, seperti yang diakui Guru Isa,

[...] aku memang cinta tanah air, tetapi dalam darahku tidak ada atau belum ada itu tradisi yang mendorong aku berkorban darah dan jiwa untuk tanah air-untuk ini aku belum pernah hidup dalam tanah air yang mesti dibela dengan darah - jadi juga jika ada orang yang berkata mempunyai semangat seperti ini, maka itu semangat ada semangat palsu dan dibikin-bikin. (JTAU: 55)

Akan tetapi, teror-teror yang datang dari luar dirinya pada titik tertentu membangkitkan kesadaran baru dalam Guru Isa. Guru Isa dapat "berdamai" dengan rasa takutnya sehingga membangkitkan darah segar, "keberanian", dalam dirinya. Keberanian itu terutama sekali muncul setelah melihat Hazil yang pada mulanya menampakkan sikap heroik, berani, ternyata mudah menyerah.

Guru Isa masih melihat terus padanya. Perlahan-lahan, amat lambat sekali, dia mengerti kata-kata yang ditangiskan Hazil, yang menjelas di sela-sela tangis dan isak-isak Hazil - aku bersalah, aku berkhianat, aku tidak tahan siksaan mereka - tidak tahan siksaan mereka - biar aku mati sekarang-aku tebus pengkhianatanku - biar aku mati-ampuni aku-ampuni aku. Dan melihat Hazil demikian Hazil perwira yang bersemangat, yang berani, selama ini, baru seminggu dalam tahanan mereka telah turun hancur menjadi seorang yang harus dikasihani, yang menangis-nangis meminta-minta ampun, sesuatu perasaan ganjil timbul dalam hati Guru Isa. (JTAU: 111)

Dalam rangka fungsi tekstualnya, novel SDJ mengukur tingkat kehidupan moral masyarakat sekaligus dari segi kebangsaan dan kemanusiaan. Orang-orang yang dekaden digambarkan sebagai orang-orang yang tidak memedulikan orang lain sebagai individu dan kelompok, yaitu rakyat kebanyakan. Orang yang korupsi adalah orang yang tidak berkebangsaan, sedangkan orang yang mencuri milik orang lain adalah orang yang tidak berkemanusiaan. Kecenderungan sintesis yang demikian ditemukan pula di dalam HH. Novel tersebut menghadirkan persoalan bahwa rasa bersalah seseorang tidak hanya dalam hubungannya dengan sesamanya sebagai individu, melainkan sesamanya sebagai kolektivitas, norma-norma masyarakatnya. Perbuatan Wak Katok membunuh temannya semasa 
perjuangan tidak saja merupakan kesalahan Wak Katok secara pribadi, sebagai individu, tetapi juga sebagai anggota masyarakat. Oleh sebab itu, Pak Balam merasa perlu mengungkit kesalahan itu di depan orang ramai karena dia juga merasa ikut bersalah dan berdosa (HH: 99). Oleh sebab itu pula, Wak Katok merasa kesal kepada sikap Pak Balam yang membuka aib pribadinya di depan orang lain. Bagi Wak Katok, perbuatannya adalah hal yang wajar, terlebih-lebih pada masa perang.

Dan sebenarnya pula, apakah sungguh dosa yang telah dilakukannya itu. Bukankah itu perbuatan perang? Di waktu perang semuanya boleh dilakukan terhadap musuh. Dan bukan dia sendiri saja yang berbuat demikian. Rupanya karena itu Pak Balam selama ini seakan mengunci diri terhadap dirinya. (HH: 106)

Demikian pula halnya dengan Pak Haji. Pak Haji mengikuti tata cara hidup orang ramai di kampungnya - berpuasa, bersembahyang di mesjid agar tidak merusak tatanan hidup bermasyarakat meskipun kepercayaannya kepada orang lain, juga kepada Tuhan, sudah hilang. Perbuatannya itu dimaksudkan agar orang lain tidak menjadi beban atas perbuatan yang pernah dilakukannya.

Dalam rangka fungsi tekstual, gagasan mengenai kemanusiaan muncul di dalam MDC, yaitu dengan cara mewujudkannya secara konkret dalam pergaulan antarbangsa. Sadeli, tokoh utama di dalam novel ini, bertualang ke luar negeri, bergaul dengan berbagai orang dari berbagai bangsa, dan akhirnya menikah dengan wanita dari bangsa lain. Tindakannya itu merupakan perwujudan falsafah hidup humanisme universal yang dipegang dan diyakininya (MDC: 137).

Akan tetapi, kecenderungan yang demikian tidak membuat persoalan kebangsaan menjadi tersisih. Kepergian Sadeli ke luar negeri dilakukan dalam rangka mengemban tugas negara. Sadeli setia kepada tugasnya dan melakukannya dengan baik. Selain berhasil menyadarkan Umar Yunus, Sadeli juga berhasil mengirimkan berbagai keperluan perjuangan melalui laut dan udara.

Juga dalam rangka fungsi tekstual, dalam novel ini konflik antara persoalan kemanusiaan dengan kebangsaan dipecahkan dalam hubungan koeksistensi. Kemanusiaan tumbuh terutama dalam hubungan antarpribadi, sedangkan kebangsaan dipertahankan terutama dalam hubungan politik dan ekonomi. Sebagai hubungan antarpribadi, Sadeli berhasil menjalin hubungan akrab dengan David Wayne, Pierre de Kooning, Dr. Banerji, Inspektur Hawkins, Maria, May Sung, dan lain-lain. Dalam hubungan antarpribadi itu secara implisit terkandung hubungan kebangsaan. Kemampuan Sadeli menjelaskan makna perjuangan bangsa Indonesia kepada Hawkins menyebabkan Hawkins manaruh hormat kepada Sadeli. Demikian pula yang terjadi pada diri Dr. Banerji, David Wayne, dan lain-lainnya. Kemampuan Sadeli seperti itu pulalah yang membuat Umar Yunus sadar akan kesalahannya dan bersedia mengembalikan uang yang dikorupsinya dan menerima penurunan pangkatnya setingkat. Dalam hal itu Sadeli terlihat mampu menyentuh 
perasaan Umar Yunus sebagai satu pribadi dan Umar Yunus sebagai bagian dari bangsa Indonesia yang tengah berjuang dan terlibat di dalamnya.

\section{HUBUNGAN INTERTEKSTUALITAS ANTARENAM NOVEL: HUBUNGAN HIPOGRAMATIK}

Hubungan hipogramatik di antara keenam teks kajian terlihat sebagai berikut. Di dalam diri Johan (TAE) yang merupakan tipe seorang petualang dan juga pejuang, sering timbul perasaan ketakutan. Ketakutan itu muncul begitu saja dari hatinya secara sporadis meskipun dengan cukup kuat. Johan digambarkan

(i) takut diserang penyakit kelamin

Di tempat tidur sendiri. Rasa takut datang. Menyesal. Takut mendapat penyakit sipilis. Dan keesokan harinya dia pergi ke dokter. Mula-mula malu benar dia mengatakan kepada dokter maksudnya datang, tetapi karena rasa takutnya kepada sipilis lebih besar, .... . (TAE: 14).

(ii) takut setiap kali menghadapi peperangan

Dalam waktu menunggu-nunggu itulah timbul takutnya. Saat antara tidak ada bahaya dan bahaya datang. Saat itu boleh jadi hanya sedikit lamanya, tetapi mungkin juga semenit, lima menit, sejam atau setengah jam, atau berjamjam. Tidak tentu. Tergantung dari keadaan. Seperti sekarang, hanya sebentar. Hanya saat-saat antara tembakan pertama dan tembakan kedua. (TAE: 21)

(iii) takut berjumpa Syarifah

Mula-mula dia merasa takut hendak berjumpa kembali. Dia takut melihat mata perempuan itu. Tidak tahu apa yang harus dikatakannya. Dia juga merasa takut dan malu berjumpa dengan orang lain di rumah itu. (TAE: 33 )

Akan tetapi, dalam rangka struktur, apa yang terjadi dalam batin Johan dan bagaimana mekanisme kehidupan batinnya tidak tergambarkan dengan cukup jelas. Bentuk-bentuk ketakutan itu terasa muncul demikian saja karena akibat munculnya ketakutan dalam ketiga contoh di atas, meskipun data tekstual tidak mengindikasikannya, cukup jelas bagi pembaca. Akan tetapi, pergolakan batin yang mengisahkan ketakutan itu tidak dieksploitasi.

Gambaran mengenai mekanisme munculnya ketakutan dalam dari Johan maupun unsur tokoh lainnya dalam JTAU baru dapat dipahami dengan baik setelah membaca kehidupan batin Guru Isa. Dalam diri Guru Isa mekanisme ketakutan itu dieksploitasi secara dalam dan luas. Pembaca seolah-olah berhadapan dengan satu wacana psikologis yang menguraikan perihal ketakutan yang melanda diri seorang manusia terhadap berbagai hal. Ketakutan yang muncul dalam diri Guru Isa serta pikiran-pikiran yang timbul dalam benaknya yang menunjukkan rasa ketakutannya itu ketika berhadapan dengan serdadu Sikh, misalnya, digambarkan dengan jelas seperti 
dalam kutipan berikut.

“Astagfirullah!" Isa berseru dalam hatinya terkejut dan ngeri ketakutan. Sekilas terbayang dalam kepalanya dia ditembak mati sekarang. Dan dia teringat pada istrinya dan Salim yang berumur empat tahun .... (JTAU: 14)

Demikian pula ketika Guru Isa ragu-ragu dan takut hendak membuktikan kebenaran keberadaan pipa rokok Hazil di bawah bantalnya sebagai satu bukti bahwa Hazil berhubungan dengan Fatimah, rasa ragu-ragu dan takut itu diperkuat dengan pergolakan batin.

Dia tahu dia tidak bisa datang pada Fatimah dengan kesepiannya. Tidak bisa datang lagi dengan ketakutannya. Dengan kengeriannya. Dengan kepiluannya. Dengan kesenangan hatinya. Kesenangan hati yang sudah jarang timbul dalam dirinya, tak obahnya sebagai orang keluar dari hutan ....

Sejak dia menemui pipa Hazil di bawah bantal-apabilakah itu, sehari yang lalu atau seabad yang lalu - maka sesuatu seakan-akan mati di dalam hatinya. Sesuatu yang segar yang betapapun juga gelap ketakutannya selalu ada di sana. Tetapi dia masih juga terlalu takut untuk mengakui bahwa ini telah hilang. Di samping ini semua masih juga dia berharap. Karena itu, maka pipa itu terus juga disimpannya diam-diam dalam laci mejanya.

Dia takut jika perkara pipa itu dibongkarnya, maka semua ketakutannya selama ini akan dibenarkan oleh pipa itu, dan ini dia hendak elakkan. Dia tahu semuanya telah habis sekarang antara dia dengan Fatimah, tetapi dia hendak memperlambat datangnya pengakuan dari dirinya sendiri. (JTAU: 95)

Apa yang terjadi dalam batin Guru Isa dan bagaimana kemudian hasil pergolakan batin itu terimplementasi dalam sikap dan tindakannya demikian jelas terungkap dalam teks ini. Dalam rangka struktur, hal serupa tidak terlihat dalam diri Johan (TAE). Pergolakan batin dalam diri Johan yang menyebabkan dia merasa kotor sekitar hubungannya dengan Syarifah (TAE: 117) dan perasaan takut setiap kali hendak menghadapi peperangan tidak dilukiskan secara rinci. Pembaca hanya dihadapkan pada pernyataan-pernyataan yang tidak menyentuh persoalan batin tokohnya. Oleh sebab itu, pembaca tidak dapat memahami secara jelas bagaimana bentuk-bentuk ketakutan itu sehingga tidak dapat menyelami batin Johan. Sebaliknya, ketika membaca kehidupan Guru Isa, pembaca justru dihadapkan pada kehidupan batin yang demikian dalam. Setiap persoalan yang timbul berimplikasi pada pergolakan batin Guru Isa. Maka, dengan membaca JTAU, khususnya dengan mencermati kehidupan Guru Isa, dapatlah dipahami kehidupan Johan dalam TAE. Hal itu disebabkan oleh eksploitasi masalah tersebut dalam rangka struktur. Dapat dikatakan bahwa Guru Isa itu merupakan potret close up batin Johan.

Selanjutnya, dekadensi moral yang terdapat di dalam novel SDJ, baik dalam bentuk dekadensi sosial, politik, maupun ekonomi, tidak dapat sepenuhnya dipahami dan dirasakan kerusakannya apabila pembaca tidak membaca novel-novel yang terbit sebelumnya. Novel-novel pertama dan 
kedua memberikan gambaran close up mengenai sejarah terbentuknya negara Indonesia, kemerdekaan Indonesia. Negara Indonesia yang merdeka itu adalah negara yang dibangun di atas pengorbanan banyak orang, pengorbanan rakyat dari segala lapisan, pengorbanan keluarga, dan pengorbanan individu. Dalam TAE, ada kematian Johan dan Hassan akibat tertembak peluru mortir, ada ketakutan ibu dan anak-anaknya, ada kefrustrasian sebagian masyarakat yang telah lama dijajah, ada kekecewaan Hassan karena perjuangan politik tidak membawa hasil yang memuaskan; dalam JTAU, ada penderitaan Hazil dan Guru Isa di dalam tahanan Belanda, ada penderitaan psikologis Guru Isa yang menyebabkan dia terserang impotensi psikis, ada orang yang terpaksa berutang dan mencuri buku sekolah sekadar untuk menghidupkan dapurnya, ada orang yang terkapar di tengah jalan karena ditembaki serdadu Sikh, dan sebagainya. Oleh sebab itu, eksploitasi para manusia dekaden dalam SDJ terpahami sebagai manusia yang bersenang-senang di atas lautan darah dan derita manusia lain, bangsa, dan rakyat Indonesia. Perilaku para pimpinan politik, pengusaha, dan sebagian masyarakat seperti Halim, Sugeng, dan Suryono, yang dengan berbagai cara berusaha memperkaya diri sendiri, serta sekelompok intelektual yang hanya pintar berdiskusi dan berdebat tanpa aksi dalam perbuatan nyata untuk meringankan beban rakyat miskin, terlihat sebagai bentuk pengkhianatan terhadap perjuangan berdarah yang telah dilakukan oleh para manusia di dalam dua novel terdahulu.

Makna dekadensi moral yang ada dalam SDJ, yang dilihat dari perspektif novel-novel sebelumnya itu, juga belumlah penuh. Makna itu akan menjadi penuh apabila persoalan tersebut dilihat dalam perspektif novel sesudahnya, TG maupun MDC. Dalam rangka fungsi tekstual TG, manusia-manusia dekaden dalam SDJ tidak hanya bersenang-senang di atas masa depan generasi sesudahnya, di atas penderitaan dan kematian Joni. Manusia dekaden yang tergambar dominan di dalam SDJ adalah manusia dalam dunia masa kini yang telah bersalah dan berdosa tidak hanya pada kehancuran dunia masa lalu, melainkan juga berdosa pada dunia masa depan. Dalam perspektif MDC, dekadensi moral itu menafikan nilai-nilai perjuangan bangsa Indonesia yang tidak lepas dari bantuan bangsa-bangsa lain. Dalam konteks ini fungsi MDC relatif sama dengan TAE dan JTAU. Lebih daripada itu, MDC seolaholah ingin menegaskan makna perjuangan sebagaimana dikatakan dalam "Pengantar" novel tersebut sebagai berikut.

Penyelewengan-penyelewengan yang dilakukan rezim Soekarno dan demikian banyak orang Indonesia di kala itu yang telah mengkhianati cita-cita perjuangan kemerdekaan bangsa kita, mendorong saya menulis buku saya sendiri untuk apa bangsa kita berjuang merebut kemerdekaan, tetapi untuk menyatakan kembali pengabadian pada cita-cita kemerdekaan bangsa kita.

Oleh sebab itu, ketika membaca seluruh novel tersebut dalam hubungan intertekstual yang demikian, terlihat sekaligus "tiga dunia" seperti tokohtokoh wayang dalam Mahabharata yang terkutip di halaman pembuka TAE sebagaimana berikut. 
“ ... putra-putramu telah bertempur dengan gagah perkasa, dan nama mereka harum dan termashur. Sesungguhnyalah mereka akan masuk sorga dan kematian mereka akan berbuah". Demikianlah Dewa Wyasa berkata kepada mereka yang sedang dalam duka nestapa. Mereka menyembah, dan akhirnya hati mereka terbujuk. Karena mereka telah dapat melihat keadaan orang-orang yang telah tewas. Dan dapat melihat ke masa yang lalu dan masa yang akan datang, melihat kepada tiga dunia.

Akan tetapi, ada yang membedakan generasi masa kini dalam Mahabharata itu dengan generasi masa kini Indonesia yang terlukis di dalam keenam novel tersebut. Generasi masa kini dalam epos tersebut adalah generasi yang berhasil "terbujuk" karena mereka mampu melihat ke arah tiga dunia sekaligus: dunia masa lalu, dunia masa kini, dan dunia yang akan datang. Mereka memiliki kearifan dan kebersihan jiwa yang dalam. Mereka mengerti akan arti dan makna perjuangan dalam arti seluas-luasnya. Sebaliknya, generasi masa kini dalam novel-novel itu adalah generasi yang hanya melihat ke satu dunia, dunia masa kininya sendiri. Mereka itu bukan generasi yang "terbujuk", mengerti, dan memiliki kearifan, melainkan generasi yang melupakan masa lalu, sejarah, tugas dan kewajiban bangsa, dan mempersetankan kehidupan yang menjadi harapan dan cita-cita bangsa sebagai satu bangsa yang makmur, aman, dan tenteram. Kehidupan generasi masa kini bertolak belakang dengan tujuan hidup yang dicita-citakan oleh bangsa Indonesia.

\section{KESIMPULAN}

Pemaknaan terhadap satu teks sastra tidak dapat semata-mata mempertimbangkan unsur-unsur yang terdapat di dalam teks itu sendiri. Pemaknaan terhadap keenam teks di atas membuktikan hal tersebut. Dalam hubungan intertekstualitas di antara keenam teksnya, terlihat adanya tiga bentuk hubungan, yakni hubungan transformatif, hubungan dialektis, hubungan hipogramatik. Keseluruhannya bermuara pada sistem pemaknaan terhadap TAE, JTAU, SDJ, TG, HH, dan MDC.

Dalam hubungan transformatif, terlihat bahwa masalah-masalah yang terdapat dalam novel TAE terungkap pula dalam novel kedua, JTAU. Hanya, bila dalam TAE persoalan ketakutan menyerang seluruh lapisan masyarakat, dalam JTAU ketakutan lebih terfokus kepada pribadi-pribadi, sedangkan dalam novel berikutnya, SDJ, ketakutan tidak lagi menduduki tempat sentral. Sebaliknya, novel ini justru memperluas dan memperdalam persoalan yang dalam novel pertama dan kedua menduduki tempat marginal, yakni kebobrokan moral masyarakat dalam rangka fungsi tekstualnya. Dalam novel ini kebobrokan menyerang seluruh lapisan masyarakat, khususnya masyarakat kelas atas, sementara kebobrokan anak-anak muda (usia tanggung) menduduki tempat di pinggiran sebagaimana terlihat pada kenakalan Jok dan Tony. Persoalan ini justru ditonjolkan dalam novel keempat, yakni TG. Dalam novel ini kebobrokan anak muda terjadi akibat tidak harmonisnya kehidupan rumah tangga, menduduki tempat sentral. Selanjutnya, dalam novel kelima, $\mathrm{HH}$, persoalan ketakutan yang relatif tidak muncul dalam novel SDJ dan TG, setelah menduduki tempat sentral dalam TAE dan JTAU, kembali berkenaan 
dengan persoalan yang di dalam novel TAE menduduki posisi marginal, yakni keampuhan diplomasi politik sebagai salah satu metode perjuangan di samping perjuangan fisik mengangkat senjata.

Dalam hubungan dialektis terlihat bahwa TAE tidak hanya menyediakan serangkaian masalah yang dapat dikembangkan, diperluas, atau dipersempit bagi novel-novel berikutnya, tetapi juga menyediakan aneka ragam masalah yang dapat dilihat dari berbagai sudut pandang. Di dalam TAE ketakutan lebih disebabkan oleh sikap egosentrisme tokoh; dalam JTAU ketakutan muncul karena adanya tekanan dari luar; dan dalam novel HH ketakutan disebabkan oleh adanya dorongan dari dalam hati karena tindakan kejahatan yang pernah dilakukan.

Selanjutnya, dalam TAE terlihat adanya konflik antara sikap kebangsaan dan sikap kemanusiaan, namun sikap kemanusiaan dikalahkan oleh kebangsaan. Akan tetapi, dalam JTAU cara pandang melihat persoalan justru berbalik. Di sini kebangsaan tidak dapat mengalahkan kemanusiaan, melainkan sebaliknya. Sikap kebangsaan yang diwakili Hazil "kalah" (menyerah pada siksaan NICA), sementara sikap kemanusiaan "menang" (timbul keberanian setelah mengalami siksaan).

Selanjutnya, dalam novel SDJ tingkat kehidupan moral masyarakat diukur sekaligus dari segi kebangsaan dan kemanusiaan. Manusia-manusia yang dekaden bukan saja tidak memedulikan manusia lain sebagai individu, tetapi juga sebagai satu masyarakat. Hal serupa terlihat pula dalam HH. Di sini rasa bersalah seseorang tidak hanya dilihat dalam hubungannya dengan sesama sebagai individu, tetapi juga sebagai kolektivitas, norma-norma masyarakat. Dalam pada itu, gagasan kemanusiaan yang dikembangkan dalam novel-novel sebelumnya dikembangkan dalam MDC, yakni dengan cara mewujudkannya secara konkret dalam pergaulan antarbangsa. Meskipun demikian, persoalan kebangsaan dan kemanusiaan dalam novel ini diselesaikan dalam hubungan koeksistensi.

Dalam hubungan hipogramatik, terlihat bahwa dalam TAE terdapat masalah yang berkaitan dengan ketakutan. Akan tetapi, apa yang terjadi dalam batin tokohnya dan bagaimana mempersoalkan mekanisme kehidupan batinnya tidak dieksploitasi. Sebaliknya, dalam rangka fungsi, hal itu justru dilakukan secara intensif dan ekstensif dalam JTAU. Karena itu, dengan membaca JTAU, kehidupan batin manusia dalam TAE dapat dipahami secara lebih baik.

Selanjutnya, dekadensi moral yang terdapat dalam SDJ tidak dapat dipahami dengan baik bila tidak dilihat dari perspektif novel-novel yang terbit sebelum dan sesudahnya. Dengan membaca novel TAE, JTAU, dan TG terpahami bahwa kebobrokan moral dalam SDJ yang mengutamakan kesenangan hidup duniawi, pada hakikatnya - selain merupakan perbuatan bersenang-senang, hidup mewah, di atas penderitaan manusia-manusia sebelumnya (TAE, JTAU) - juga merampas masa depan generasi sesudahnya (TG). 


\section{DAFTAR ACUAN}

Culler, Jonathan (1981), The Pursit of Signs. Semiotics, Literature, Deconstruction. London: Routledge \& Kegan Paul.

Riffaterre, Michael (1978), Semiotics of Poetry. Bloominton: Indiana University Press.

Zaimar, Okke K.S. (1990), Menelusuri Makna Ziarah Karya Iwan Simatupang. Jakarta: Intermasa.

SUMBER DATA

Lubis, Mochtar (1952/1990), Jalan Tak Ada Ujung. Jakarta: Pustaka Jaya.

Lubis, Mochtar (1981a), Senja di Jakarta. Jakarta: Pustaka Jaya.

Lubis, Mochtar (1981b), Mitos dan Komunikasi. Jakarta: Sinar Harapan.

Lubis, Mochtar (1982), Tanah Gersang. Jakarta: Pustaka Jaya.

Lubis, Mochtar (1989a), Maut dan Cinta. Jakarta: Pustaka Jaya.

Lubis, Mochtar (1989b), Tidak Ada Esok. Jakarta: Pustaka Jaya. 